\begin{tabular}{|c|c|}
\hline SILAMPARI B MISA & $\begin{array}{l}\text { PRINTED ISSN: } 2620-6919 \\
\text { ONLINE ISSN: } 2620-3316\end{array}$ \\
\hline $\begin{array}{l}\text { Published by LP4MK STKIP PGRI LUBUKLINGGAU } \\
\text { Prodi Pendidikan Bahasa Indonesia, STKIP PGRI Lubuklinggau, } \\
\text { South Sumatera, Indonesia }\end{array}$ & $\begin{array}{r}\text { Vol. 1, No. 1, } 2018 \\
\text { Page: 174-188 }\end{array}$ \\
\hline
\end{tabular}

\title{
PENGARUH MODEL PEMBELAJARAN WRITING IN THE HERE AND NOW DALAM MENULIS BAHAN AJAR MAHASISWA PROGRAM STUDI PENDIDIKAN BAHASA INDONESIA STKIP PGRI LUBUKLINGGAU
}

\author{
Marianita ${ }^{1} \&$ Artati $^{2}$ \\ 1,2 Program Studi Pendidikan Bahasa Indonesia, STKIP PGRI Lubuklinggau \\ Jln. Mayor Toha Kelurahan Air Kuti, Kota Lubuklinggau, 31625, Indonesia \\ Email: marianita@gmail.com, artati@yahoo.com
}

Submitted: 29-May-2018

Accepted: 30-June-2018
Published:30-June-2018 DOI: 10.31540/silamparibisa.v1i1.22

URL: https://doi.org/10.31540/silamparibisa.v1i1.22

\begin{abstract}
Abstrak
Tujuan penelitian ini untuk mengetahui pengaruh model pembelajaran writing in the here and now dalam menulis bahan ajar mahasiswa semester VI Program Studi Pendidikan Indonesia STKIP PGRI Lubuklinggau tahun akademik 2017/2018. Jenis penelitian yang digunakan yaitu metode eksperimen murni dengan desain bentuk pretest dan post test group desain. Teknik pengumpulan data dengan teknik tes. Teknik analisis data dimulai dengan uji normalitas data, uji homogenitas, dan uji t. Berdasarkan hasil penelitian dapat dibuktikan bahwa terdapat pengaruh yang signifikan model pembelajaran writing in the here and now dalam menulis bahan ajar mahasiswa semester $\mathrm{VI}$ Program Studi Pendidikan Indonesia STKIP PGRI Lubuklinggau tahun akademik 2017/2018. Hal ini ditunjukkan dengan nilai tabel dengan dk yaitu 60 . Dengan demikian, thitung $(5,37)$ lebih besar dari ttabel $(2,00)$ untuk taraf signifikan $5 \%$ dengan $\mathrm{dk}=60$. Hal ini berarti Ho ditolak dan Ha diterima.
\end{abstract}

Kata kunci: pengaruh, model writing in the here and now, menulis bahan ajar

\section{THE EFFECT OF LEARNING MODEL WRITING IN THE HERE AND NOW IN WRITING MATERIALS INDONESIA LANGUAGE EDUCATION STUDY PROGRAM COLLEGE STUDENT STKIP-PGRI LUBUKLINGGAU}

\begin{abstract}
The objective of this research was to know the effect of learning model of writing in the here and now in writing the material of student semester VI Indonesia Language Education Study Program STKIP PGRI Lubuklinggau academic year 2017/2018. The type of research used is pure experimental method with pretest shape design and post test group design. Technique of collecting data with test technique. Data analysis technique begins with data normality test, homogeneity test, and test. Based on the results of research can be proved that there is a significant influence of learning model writing in the here and now in writing teaching materials students semester VI Indonesia Language Education Study Program STKIP PGRI Lubuklinggau academic year 2017/2018. This is shown by ttable value with dk that is 60 . Thus, tcount $(5,37)$ is bigger than ttable $(2.00)$ for $5 \%$ significant level with $\mathrm{dk}=60$. This means $\mathrm{Ho}$ is rejected and $\mathrm{Ha}$ accepted.
\end{abstract}

Keywords: effect, model writing in the here and now, writing materials 


\section{A. Pendahuluan}

Penyampaian materi pelajaran hanyalah merupakan salah satu unsur dari dari berbagai kegiatan perkuliahan sebagai suatu proses perkembangan mahasiswa. Peran dosen dalam proses perkuliahan tidak hanya terbatas sebagai pengajar yang sedemikian rupa, tetapi dapat merangsang mahasiswa untuk belajar secara aktif dan dinamis dalam memenuhi kebutuhan dan menciptakan tujuan, baik di sekolah formal maupun di tempat-tempat pendidikan nonformal. Hal ini sesuai dengan pendapat Noermanzah (2015:274) bahwa beberapa peran dosen yaitu: (1) menjadi model dalam menggunakan bahasa Indonesia, baik lisan maupun tulisan secara santun dalam setiap kegiatan pembelajaran dengan pola mendidik, mengajar, dan melatih; (2) menciptakan pembelajaran yang kreatif dan berpikir kritis; (3) memberikan kemampuan kepada mahasiswa dalam mengelola industri kreatif, baik bidang kebahasaan maupun kesastraan Indonesia; (4) menjadi fasilitator dalam membentuk media sosial atau komunitas ilmiah berkaitan dengan permasalahan bahasa dan sastra Indonesia; (5) memberikan sumber belajar berbasis online dan tugas kepada mahasiswa yang harus dipublikasikan secara online; (6) menyusun bahan ajar atau penelitian bersama mahasiswa dengan menggunakan bahasa Indonesia dan mempubilkasikannya secara online; dan (7) memfasilitasi mahasiswa dalam kegiatan-kegiatan ilmiah atau sastra dan memfasilitasi kerja sama dalam pertukaran mahasiswa Bahasa dan Sastra Indonesia dan peluang kerja bagi guru bahasa Indonesia untuk mengajar, baik di dalam maupun di luar negeri.

Pada poin 6, di atas, dosen dituntut mampu memberikan pengajaran tentang bagaimana menyusun bahan ajar kepada mahasiswa. Mahasiswa dipersiapkan sebagai calon pendidik yang berkualitas, mampu memenuhi kebutuhan siswa, seperti menulis bahan ajar sesuai dengan kebutuhan siswa. Menulis bahan ajar merupakan salah satu kompetensi dasar yang harus dikuasai oleh calon guru pendidikan bahasa Indonesia. Menurut Morsey (dalam Tarigan, 2008:4), menulis merupakan proses melaporkan, memberitahukan, dan mempengaruhi, dan bertujuan dengan menuangkan pikiran ke dalam bentuk tulisan dengan organisasi kalimat yang informatif. 
Berdasarkan pendapat di atas, menulis adalah salah satu bentuk komunikasi tidak langsung dengan menggunakan bahasa tulis sebagai medianya. Menulis juga merupakan kegiatan yang dilakukan oleh seseorang untuk menghasilkan sebuah karya. Kegiatan menulis juga sebagai keterampilan seseorang dalam menuangkan ide ke dalam tulisan. Jadi menulis merupakan suatu proses kreatif memindahkan gagasan ke dalam lambang-lambang tulisan. Keterampilan menulis tidak hanya menghasilkan suatu tulisan, tetapi terdapat tujuan dan proses menulis itu sendiri.

Terdapat beberapa macam tujuan penulisan menurut Hugo Hartig (dalam Tarigan, 2008:25-26), yaitu: pertama, tujuan penugasan (assigment purpose) yaitu penulis melaksanakan tugasnya untuk menulis karena mendapatkan tugas. Jadi menulis bukan berdasarkan kemauan dari diri sendiri. Contohnya siswa mendapatkan tugas untuk menulis berita. Kedua, tujuan altruistik (altruistio purpose). Pada tujuan altruistik penulis bentujuan untuk menyenangkan pembaca dengan menolong pembaca untuk memahami tulisannya, menghargai perasaan dan penalaranya, membuat hidup para pembaca lebih mudah dan lebih menyenangkan dengan karya tulis yang telah dibuat karena mudah untuk dipahami.

Ketiga, tujuan persuasif (persuasive purpose). Persuasif merupakan ajakan, sehingga penulis meyakinkan pembaca untuk percaya akan kebenaran gagasan yang diutarakannya melalui ditulisan. Contohnya penulisan tentang bahaya narkoba sehingga pembaca diajak untuk menjauhi narkoba. Keempat, tujuan informasional (informational purpose). Tujuan ini yang memberikan informasi atau keterangan kepada pembaca tanpa mempengaruhi pembaca. Contohnya menulis teks berita tentang kecelakaan Ialu lintas. Kelima, tujuan pernyataan diri (self-ekspressive purpose), merupakan perkenalan atau pengarang mengenalkan diri kepada pembaca. Keenam, tujuan kreatif (creative purpose). Hampir sama dengan tujuan pernyataan diri, hanya saja yang membedakan dalam tulisan ini terdapat nilai keindahannya karena pengarang kreatif serta terdapat norma artistik. Contohnya penulisan cerpen, puisi, atau novel. Ketujuh, tujuan pemecahan masalah (problem solved purpose), penulis dalam tujuan ini ingin memecahkan masalah yang sedang dihadapi, jadi penulis meluruskan, menjelaskan, menjernihkan, menjelajahi serta 
meneliti dengan cermat gagasan apa yang sedang dipikirkan penulis agar dapat dimengerti dan di terima oleh pembaca.

Berdasarkan pendapat di atas, disimpulkan bahwa tujuan menulis terbagi menjadi beberapa bagian. Menulis penugasan sebagai kegiatan menulis dengan tujuan mendapat tugas, jadi bukan dari kemauannya sendiri. Menulis altruistik sebagai kegiatan menulis dengan tujuan menyenangkan membaca untuk menghargai tulisanya. Menulis sebagai pemecah masalah bertujuan sebagai menulis untuk memecahkan masalah, misalnya menulis bahan ajar, yang memecahkan masalah siswa yang kurang kurang tertarik dengan materi yang diajarkan oleh guru. Tujuan menulis bermacam-macam disesuaikan dengan kebutuhan seseorang tersebut dalam membuat sebuah tulisan.

Kemudian, menulis bahan ajar berdasarkan beberapa tujuan menulis di atas, dapat digolongkan ke dalam jenis tulisan dengan tujuan penugasan. Menurut Kitao, dkk. (dalam Yaumi, 2013:243) bahwa bahan ajar merupakan materi yang disediakan untuk memenuhi kebutuhan pembelajaran yang mencakup buku teks, video dan audiotapes, softwere computer, dan alat bantu visual. Bahan ajar memiliki beragam jenis, ada yang cetak maupun noncetak. Bahan ajar cetak yang sering dijumpai antara lain berupa handout, buku, modul, brosur, dan lembar kerja siswa.

Pemilihan bahan ajar dan pengembangan bahan ajar merupakan tuntutan pendidik dalam kegiatan profesinya. Bahan ajar biasanya bersifat mandiri, sebab seorang pendidik dapat menemukan, mencari, dan mengembangkan bahan ajar sesuai dengan kebutuhan peserta didiknya. Bahan ajar yang dikembangkan juga tidak keluar pada jalur standar isi. Hal ini diperkuat oleh pendapat Prastowo (2011:19), bahwa mutu sebuah pembelajaran menjadi rendah ketika pendidikan hanya terpaku pada bahan-bahan ajar yang bersifat konvensional tanpa ada kreativitas untuk mengembangkan bahan ajar tersebut secara inovatif.

Bahan ajar adalah segala bentuk bahan pembelajaran, baik cetak, audiovisual, maupun bentuk lain yang dikumpulkan dari berbagai sumber. Tampilan dikemas lebih menarik dan tidak keluar dari standar kompetensi, gunanya untuk memudahkan dalam kegiatan pembelajaran di kelas dan bertujuan 
memotivasi siswa agar materi yang disampaikan dapat diterima sehingga indikator pembelajaran tercapai.

Tujuan dari mata kuliah seperti yang telah dijelaskan di atas adalah mahasiswa mampu menulis bahan ajar. Oleh karena itu, hendaknya mahasiswa mampu menulis bahan ajar sederhana yang sesuai dengan kebutuhan. Akan tetapi lebih dari itu, mahasiswa mengalami kesulitan dalam menulis bahan ajar. Namun kenyataannya, setelah peneliti memberi perkuliahan mata kuliah ini di Program Studi Pendidikan Bahasa Indonesia di STKIP-PGRI Lubuklinggau, banyak persoalan yang dihadapi mahasiswa ketika menulis bahan ajar. Mahasiswa tidak mampu menulis bahan ajar yang sesuai dengan kebutuhan siswa menyebabkan rendahnya nilai yang diperoleh mahasiswa untuk mengembangkan bahan ajar.

Apabila dicermati salah satu faktor yang diduga sebagai penyebab rendahnya kualitas mahasiswa adalah kurangnya pengetahuan mengenai bahan ajar. Rendahnya pengetahuan itu menyebabkan mahasiswa menjadi malas ketika diberikan tugas untuk menulis bahan ajar. Seharusnya mahasiswa mampu menulis bahan ajar kuliah. Banyak kendala yang menyebabkan kurangnya kemampuan mahasiswa dalam menulis bahan ajar tersebut.

Dosen harus betul-betul mempertimbangkan pemilihan model yang tepat dalam pembelajaran, sehingga potensi dan daya kreativitas siswa dapat tersalurkan dengan baik, tidak hanya potensi yang terpendam. Brown (dalam Suyatinah, 2003:131) menyatakan bahwa:

"Untuk meningkatkan partisipasi aktif fisik dan mental siswa, guru hendaknya tidak mendominasi aktivitas belajar mengajar, tetapi memberikan kesempatan seluasluasnya pada siswa untuk berinteraksi dengan guru, dengan materi pelajaran maupun dengan sesama siswa. Dalam belajar, siswa membutuhkan bantuan tenaga pendidik yang mampu menstimulasi dan menyugesti mereka ke dalam dunia pendidikan".

Sehubungan dengan pendapat tersebut dapatlah diartikan bahwa untuk dapat menstimulasi dan menyugesti mahsiswa, dosen harus mampu dan cakap dalam menerapkan model pembelajaran yang tepat sehingga berindikasi pada keberhasilan siswa dalam belajar. Salah satu model pembelajaran yang dapat digunakan adalah model writing in the here and now. 
Menurut Silberman (2011:198), model pembelajaran writing in the here and now merupakan aktivitas menulis yang memungkinkan mahasiswa untuk memikirkan pengalaman yang mereka miliki secara mandiri. Sebuah cara dramatis untuk meningkatkan perenungan secara mandiri adalah dengan meminta mahasiswa menuliskan laporan tindakan tentang sebuah pengalaman yang mereka miliki. Sedangkan menurut Komaruddin (2007:186), model pembelajaran writing in the here and now merupakan proses kegiatan menulis yang membantu siswa merefleksikan pengalaman-pengalaman yang telah mereka alami selama ini. Cara dramatis untuk memajukan refleksi independen adalah meminta siswa menulis laporan tindakan saat sekarang dari sebuah pengalaman yang telah mereka alami (seolah-olah tindakan ini terjadi di sini dan sekarang). Berdasarkan definisi di atas, model pembelajaran writing in the here and now adalah aktivitas dalam proses belajar dengan menuangkan gagasan ke dalam tulisan pada saat itu juga yang diperoeh dari pengalaman pribadi.

Melalui model pembelajaran writing in the here and now ini, mahasiswa akan termotivasi untuk mengikuti proses belajar mengajar dengan aktif dan menyenangkan karena mahasiswa dihargai karyanya dari pengalaman pribadinya. Selain itu, dapat menumbuhkan keterampilan berpartisipasi mahasiswa siswa dalam pembelajaran menulis bahan ajar. Model pembelajaran writing in the here and now digunakan dalam penelitian ini, dimaksudkan untuk membantu mahasiswa mencapai hasil belajar yang optimal sesuai kompetensi yang diharapkan dalam menulis bahan ajar.

Penelitian relevan yang penulis gunakan adalah penelitian oleh Wulandari (2012:x) yang berjudul "Penggunaan Model Pembelajaran Writing In The Here and Now untuk Meningkatkan Hasil Belajar tentang Materi Menulis Siswa Kelas III SDN Ampeldento 2 Kecamatan Karangploso Kabupaten Malang". Hasil penelitian menunjukkan bahwa keterlaksanaan model pembelajaran writing in the here and now pada siklus I mencapai $83 \%$ yang mengalami peningkatan pada siklus II yaitu $100 \%$. Persentase ketuntasan pada siklus I mencapai 44\% dengan KKM sebesar 70. Sedangkan pada siklus II persentase ketuntasan mencapai $88,3 \%$. Hasil penelitian ini menunjukkan bahwa penggunaan model pembelajaran writing in the 
here and now dapat meningkatkan hasil belajar bahasa Indonesia siswa kelas III SDN 2 Ampeldento Malang.

Dari hasil penelitian relevan ini menunjukkan bahwa model pembelajaran writing in the here and now mampu meningkatkan kemampuan menulis siswa. Selain itu juga, belum dilaksanakan penelitian untuk meningkatkan kemampuan mahasiswa dalam menulis bahan ajar. Dengan hasil penelitian ini diharapkan selain mampu meningkatkan kemampuan mahasiswa dalam menulis bahan ajar, juga model pembelajaran writing in the here and now dapat dijadikan salah satu model pembelajaran yang dapat digunakan dalam materi lain yang menuntut kegiatan mahasiswa dalam menulis.

\section{B. Metode Penelitian}

Penelitian ini menggunakan metode pendekatan kuantitatif dengan metode eksperimen murni. Desain penelitian dalam bentuk pretest dan post test group desain. Metode eksprimen murni, yaitu jenis-jenis eksprimen yang dianggap sudah baik karena memenuhi persyaratan yaitu adanya kelompok lain (kontrol) dan ikut mendapat pengamatan. Dengan adanya kelompok kontrol dapat diketahui secara pasti karena membandingan dengan kelompok yang tidak mendapat perlakuan (Arikunto, 2010: 86).

Dalam penelitian ini writing in the here and now digunakan sebagai kelas eksperimen, sedangkan kelas kontrol diberi perlakuan dengan menggunakan metode ceramah. Dalam penelitian ini bertujuan untuk melihat pengaruh writing in the here and now. Pada akhir penelitian ini kelas eksprimen dan kelas kontrol diberi tes akhir untuk melihat model pembelajaran yang digunakan berpengaruh atau tidak dalam penelitian. Penelitian ini terdapat dua variabel yakni variabel bebas disimbolkan dengan $\mathrm{X}$ (writing in the here and now) sedangkan variabel terikat disimbolkan dengan $\mathrm{Y}$, yaitu kemampuan menulis bahan ajar.

Teknik pengumpulan data menggunakan teknik tes dalam bentuk tes uraian. Kemudian, langkah-langkah analisis data dimulai dari menentukan nilai rata-rata dan simpangan baku pada data pretes dan postes, untuk data hasil belajar pada kelas eksperimen dan kelas kontrol. Uji normalitas ini digunakan untuk mengetahui 
kenormalan data, rumus yang digunakan untuk menghitung uji normalitas adalah Chi-Kuadrat (Sugiyono, 2012:107).

Kemudian, dilakukan uji homogenitas varians antara dua kelompok dimaksudkan untuk mengetahui keadaan varians antara dua kelompok, sama ataukah berbeda. Pengujian homogenitas ini menguji uji varians dua buah perubah. Langkah analisis data yang terakhir yaitu, uji hipotetsis. Hipotesis dalam penelitian ini adalah "Ada pengaruh yang signifikan model pembelajaran writing in the here and now terhadap kemampuan menulis bahan ajar". Untuk menguji hipotesis penelitian digunakan rumus uji "t" dengan rumus $t$-tes dengan taraf signifikansi $5 \%$ yang dikemukakan oleh Sugiyono (2012:86).

\section{Hasil Penelitian dan Pembahasan}

\section{Hasil Penelitian}

Model pembelajaran yang diterapkan adalah sehari sebelum pertemuan pertama dilaksanakan, penulis memperkenalkan tentang writing in the here and now. Pada proses pelaksanaan penelitian, dimulai dengan pengerjaan tes awal (pretes) untuk mengetahui kemampuan awal mahasiswa dalam menulis bahan ajar yang akan dipelajari pada kelas eksperimen dan kelas kontrol. Tes awal (pretes) dilaksanakan untuk mengetahui kemampuan awal siswa sebelum diberikan perlakuan pada penelitian. Setelah pelaksanaan tes awal (pretes), maka dilakukan treatment atau perlakuan pembelajaran dengan menggunakan writing in the here and now untuk kelas eksprimen dan pembelajaran menggunakan metode ceramah untuk kelas kontrol. Selanjutnya, setelah pelaksanaan treatment atau perlakuan, penulis mengadakan tes akhir (postes). Pelaksanaan postes berfungsi untuk mengetahui hasil belajar mahasiswa setelah mengikuti proses belajar mengajar yang dilaksanakan. Tes akhir bertujuan untuk mengetahui kemampuan akhir mahasiswa setelah diberikan perlakuan pada penelitian.

a. Deskripsi Hasil Tes

1) Kemampuan Awal Siswa (Pretest)

Kemampuan awal diperoleh melalui tes, baik kelas eksperimen maupun kelas kontrol pada menulis bahan ajar. Pelaksanaan tes awal diikuti oleh 30 siswa 
pada kelas eksperimen dan 32 pada kelas kontrol. Tes awal dilakukan untuk mengetahui kemampuan awal siswa, baik kelas eksprimen maupun kelas kontrol "Apakah" kedua kelas tersebut memiliki kemampuan awal yang sama atau tidak sebelum dilakukan penerapan pembelajaran. Dari hasil perhitungan, diketahui bahwa nilai terendah yang diperoleh siswa pada kelas eksperimen adalah 44 dan nilai tertinggi yang diperoleh siswa adalah 83, dengan nilai rata-ratanya adalah 63,20 , sehingga kemampuan siswa kelas eksperimen sebelum diberi pembelajaran dengan menerapkan model pembelajaran writing in the here and now. Sedangkan hasil perhitungan kelas kontrol nilai terendah yang diperoleh siswa adalah 42 dan nilai tertinggi yang diperoleh adalah 83 dengan rata-rata adalah 59,16 sehingga kemampuan siswa kelas kontrol belum mencapai indikator. Mahasiswa yang mendapat nilai $\geq 70$ dengan kriteria tuntas untuk kelas eksperimen dari 30 orang mahasiswa adalah 8 orang (26,67\%), dan yang mendapat nilai $<70$ dengan kriteria tidak tuntas adalah 22 orang $(73,33 \%)$. Sedangkan untuk kelas kontrol mendapat nilai $\geq 70$ dengan kriteria tuntas dari 32 orang mahasiswa adalah 8 orang $(25 \%)$, dan yang mendapat nilai $<70$ dengan kriteria tidak tuntas adalah 24 orang $(75 \%)$.

\section{2) Kemampuan Akhir Siswa (Postest)}

Kemampuan yang dimiliki mahasiswa setelah kegiatan pembelajaran menulis bahan ajar, data penelitian diperoleh dari hasil postest (tes akhir). Postest dilakukan untuk melihat hasil belajar siswa baik kelas eksprimen maupun kelas kontrol, apakah kedua kelompok perlakuan tersebut mencapai Kriteria Ketuntasan Minimum (KKM) atau tidak setelah dilakukan pembelajaran dengan model pembelajaran yang berbeda. Dari hasil perhitungan, diketahui bahwa nilai terendah yang diperoleh dari 30 mahasiswa pada kelas eksperimen adalah 56 dan nilai tertinggi yang diperoleh mahasiswa adalah 94, sedangkan nilai rata-ratanya adalah 83,17 , sehingga kemampuan siswa kelas eksperimen sesudah diberi pembelajaran dengan menerapkan writing in the here and now telah mencapai ketuntasan.

Sedangkan hasil perhitungan kelas kontrol dari 32 siswa nilai terendah yang diperoleh siswa adalah 44 dan nilai tertinggi yang diperoleh adalah 89 dengan ratarata adalah 67,34 , sehingga kemampuan mahasiswa kelas kontrol belum mencapai 
ketuntasan. nilai akhir mahasiswa yang mendapat nilai $\geq 70$ dengan kriteria tuntas untuk kelas eksperimen dari 30 orang mahasiswa adalah 28 orang $(93,33 \%)$, dan yang mendapat nilai $<70$ dengan kriteria tidak tuntas adalah 2 orang $(6,67 \%)$. Sedangkan untuk kelas kontrol mendapat nilai $\geq 70$ dengan kriteria tuntas dari 32 orang siswa adalah 14 orang $(46,67 \%)$, dan yang mendapat nilai $<70$ dengan kriteria tidak tuntas adalah 18 orang (53,33\%). Jadi dapat disimpulkan bahwa kelas eksperimen telah mencapai ketuntasan secara klasikal karena jumlah siswa yang tuntas lebih dari $85 \%$ atau $93,33 \%>85 \%$.

\section{b. Pengujian Hipotesis}

1). Menentukan Nilai Rata-rata dan Simpangan Baku

Berdasarkan penghitungan yang telah dilakukan, didapatkan nilai rata-rata dan simpangan baku, baik pada kegiatan pretest dan postest pada kelas eksperimen dan kelas kontrol adalah seperti di bawah ini:

\begin{tabular}{ccccc}
\multicolumn{2}{c}{ Tabel 1. Hasil Penghitungan Rata-Rata dan Simpangan Baku } \\
\hline \multirow{2}{*}{ Variabel } & \multicolumn{2}{c}{ Kelas Eksperimen } & \multicolumn{2}{c}{ Kelas Kontrol } \\
\cline { 2 - 5 } & $\begin{array}{c}\text { Rata-Rata } \\
(\bar{x})\end{array}$ & $\begin{array}{c}\text { Simpangan } \\
\text { baku }\end{array}$ & $\begin{array}{c}\text { Rata-rata } \\
(\bar{x})\end{array}$ & $\begin{array}{c}\text { Simpangan } \\
\text { Baku }\end{array}$ \\
\hline Pretest & 63,20 & 9,75 & 59,16 & 12,52 \\
\hline Postest & 83,17 & 9,32 & 67,34 & 13,48 \\
\hline
\end{tabular}

\section{2). Uji Normalitas Data}

Kriteria pengujian normalitas data, dengan taraf kepercayaan $a=0,05$ dan $\mathrm{dk}=\mathrm{j}-1$, yang mana $\mathrm{j}$ adalah banyaknya kelas interval, jika $x^{2}$ hitung lebih kecil $\mathrm{X}^{2}$ tabel, maka data dapat disimpulkan berdistribusi normal. Dalam hal ini hasil uji normalitas menunjukkan bahwa $X^{2}$ hitung data tes awal dan data tes akhir kelas eksperimen dan kelas kontrol kurang dari $X^{2}$ tabel. Nilai $X^{2}$ itung data tes awal untuk kelas eksperimen adalah 7,46, sedangkan untuk kelas kontrol adalah 4,74 dengan $X^{2}$ tabel adalah 11,07 . Berarti $X^{2}$ hitung lebih kecil dari pada $X^{2}$ tabel. Sedangkan nilai $X^{2}$ hitung data tes akhir kelas eksperimen adalah 4,73 , dan nilai $X^{2}$ hitung data tes akhir kelas kontrol adalah 6,73 , dengan $X^{2}$ abel adalah 11,07 . Berarti $X^{2}$ itung lebih kecil dari pada $X^{2}$ tabel. Dengan demikian, pengujian normalitas dengan rumus Chi-kuadrat dapat disimpulkan bahwa dengan taraf kepercayaan 0,05 dan (dk) $=5$ adalah berdistribusi normal. 
3). Uji Homogenitas Data

Kriteria pengujian tolak $\mathrm{H}_{0}$, jika $F_{\text {hitung }}$ lebih kecil dari $F_{\text {tabel }}$ dengan taraf signifikansi $5 \%$, dk $1=\left(\mathrm{n}_{1}-1\right)$ dan $\mathrm{dk}=\left(\mathrm{n}_{2}-1\right)$. Menurut hasil perhitungan analisis data tentang uji homogenitas varians tes awal dan tes akhir. Dibuktikan

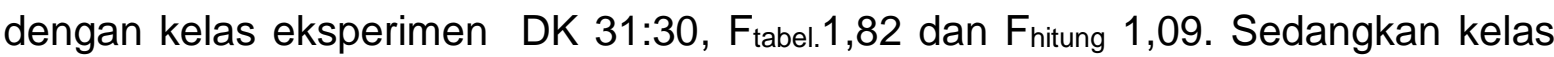
kontrol dengan DK 31:30, dengan Ftabel.1,82 dan Fhitung 1,16. Dari deskripsi itu bahwa varians kedua kelompok pada kelas eksperimen dan kontrol tersebut adalah homogen, karena F Fitung lebih kecil dari pada $F_{\text {tabel.I }}$

\section{4). Uji Hipotesis}

Berdasarkan hasil perhitungan yang telah dilakukan penulis didapatkan thitung $=5,38$. Selanjutnya, thitung dikonsultasikan dengan tabel pada daftar distribusi $t$ dengan taraf signifikan $5 \%$ pada derajat kebebasan $\mathrm{dk}=\mathrm{n}_{1}+\mathrm{n}_{2}-2=30+32-2=$ 60. Nilai tabel dengan $d k=60$. Dengan demikian, thitung $(5,37)>$ tabel $(2,00)$ untuk taraf signifikan $5 \%$ dengan $\mathrm{dk}=60$. Hal ini berarti Ho ditolak dan Ha diterima. Dengan demikian, hipotesis yang diajukan dalam penelitian ini dapat diterima kebenarannya, bahwa ada pengaruh yang signifikan model pembelajaran writing in the here and now terhadap kemampuan menulis bahan ajar mahasiswa semester VI Program Studi Pendidikan Bahasa Indonesia.

\section{Pembahasan}

Berdasarkan penelitian yang telah dilakukan, maka model pembelajaran writing in the here and now dapat dijadikan alternatif dalam proses belajar mengajar, khususnya pembelajaran menulis bahan ajar. Hal ini sesuai dengan pendapat Komaruddin (2007:186) bahwa model pembelajaran writing in the here and now sebagai proses kegiatan menulis yang membantu siswa merefleksikan pengalaman-pengalaman yang telah mereka alami selama ini. Pada penelitian yang dilakukan, penulis mengajar dua kelas yakni kelas VI.A kelas eksprimen dan kelas VI.C untuk kelas kontrol. Dari hasil penelitian yang dilakukan terhadap sampel yang berjumlah 30 dari VI.A yang merupakan kelas eksprimen dan kelas VI. C 
berjumlah 32 mahasiswa yang nerupakan kelas kontrol, kedua kelas tersebut berdistribusi normal dan berdasarkan hasil populasi yang homogen.

Rata-rata skor postest kelas eksprimen relatif lebih besar dari kelas kontrol. Hasil rata-rata pretes kelas eksperimen adalah 63,20 sedangkan kelas kontrol yaitu 59,16 . Selisih skor rata-rata pretes kelas eksprimen dan kelas kontrol adalah 4,04. Hal ini menunjukkan bahwa skor rata-rata pretes kelas eksprimen tidak jauh berbeda dengan skor rata-rata pretes kelas kontrol. Selanjutnya, rata-rata postes kelas eksperimen yaitu 83,17 sedangkan kelas kontrol adalah 67,34 . Selisih skor rata-rata postes antara kelas eksprimen dan kelas kontrol adalah 15,83. Hal ini menunjukkan bahwa skor rata-rata postes kelas eksprimen cukup jauh berbeda dengan rata-rata postes kelas kontrol.

Berdasarkan analisis data untuk pretes dari jumlah siswa $(\mathrm{N})$ kelas eksperimen 30 siswa dan kelas kontrol 32 siswa, diperoleh rata-rata nilai kelas eksperimen adalah 63,20 dan rata-rata nilai kelas kontrol adalah 59,16. Untuk simpangan baku kelas eksperimen adalah 9,75dan simpangan baku kelas kontrol adalah 12,52. Pada nilai pretest kelas eksperimen untuk Xmin adalah 44 dan Xmaks 83 dan kelas kontrol Xmin adalah 42 dan Xmaks 83. Kemudian, siswa yang tuntas pada kelas eksperimen adalah 8 orang siswa atau $26,67 \%$ dan yang tidak tuntas adalah 22 orang siswa atau 73,33\%. Sedangkan pada kelas kontrol siswa yang tuntas adalah 8 orang siswa atau 25\% dan siswa yang tuntas adalah 24 orang siswa atau $75 \%$. Hal ini terjadi disebabkan pada kegiatan awal (pretest) siswa belum diberikan perlakuan dengan menggunakan model pembelajaran yang tepat dan kurangnya motivasi siswa untuk lebih fokus dalam pembelajaran, sehingga membuat siswa kurang aktif dan pembelajaran menjadi satu arah serta tidak terjadi timbal balik dan respons mahasiswa dalam menulis bahan ajar, karena proses pembelajaran tidak membuat mahasiswa termotivasi dan aktif dalam mengikuti pembelajaran. Selain itu, kurangnya sumber belajar mahasiswa seperti buku pelajaran sebagai sumber pembuatan bahan ajar yang ada di perpustakaan, sehingga siswa kesulitan dalam memahami proses menyusun bahan ajar.

Sedangkan untuk postest dari jumlah siswa $(\mathrm{N})$ kelas eksperimen 30 siswa dan kelas kontrol 32, diperoleh nilai rata-rata eksperimen 83,17 dan nilai rata-rata 
kelas kontrol adalah 67,34 dengan simpangan baku kelas eksperimen adalah 9,32 dan simpangan baku kelas kontrol adalah 13,48. Nilai postest kelas eksperimen untuk Xmin adalah 56 dan Xmaks adalah 94 dan nilai postes kelas kontrol untuk Xmin adalah 44 dan Xmaks 89. Kemudian, siswa yang tuntas pada kelas eksperimen adalah 28 orang siswa atau $93,33 \%$ dan yang tidak tuntas adalah 2 orang mahasiswa atau $6,67 \%$. Sedangkan pada kelas kontrol mahasiswa yang tuntas adalah 14 orang mahasiswa atau $46,67 \%$ dan mahasiswa yang tidak tuntas adalah 18 orang mahasiswa atau $53,33 \%$. Terlihat bahwa rata-rata skor postest kelompok eksperimen relatif lebih besar dari kelompok kontrol dan mahasiswa yang tuntas pada kelas eksperimen relatif lebih banyak dibandingkan kelas kontrol.

Selisih skor rata-rata pretest kelas eksperimen dan kelas kontrol adalah 4,05. Hal ini menunjukkan bahwa skor rata-rata pretest kelas eksperimen tidak jauh berbeda dengan skor rata-rata pretest kelas kontrol. Sedangkan selisih skor ratarata postest antara kelas eksperimen dan kelas kontrol adalah 15,83. Hal ini menunjukkan bahwa skor rata-rata postest kelas eksperimen cukup jauh berbeda dengan skor rata-rata postes kelas kontrol. Hal ini terjadi karena model pembelajaran writing in the here and now yang diterapkan dalam memecah suatu permasalahan yang memiliki jawaban beragam dari mahasiswa, sebab model ini dapat digunakan dalam pemecahan berbasis masalah. Model pembelajaran writing in the here and now ini mendorong mahasiswa untuk dapat memberikan partisipasi dalam pembelajaran, siswa berikan kesempatan untuk memecahkan masalah dan memberikan jawaban yang beragam, membuat suasana pembelajaran yang kooperatif antara mahasiswa dengan mahasiswa dan antara siswa dengan guru sehingga lebih memotivasi siswa untuk saling membantu, berdiskusi, dan berargumentasi dengan mengemukaan idenya. Harapannya sumber informasi yang diterima siswa tidak hanya dari guru, tetapi juga dapat meningkatkan peran serta keaktifan siswa dalam mempelajari dan memahami materi menulis bahan ajar.

Berdasarkan pengujian hipotesis diperoleh thitung $=5,38$ dan setelah dikonsultasikan dengan tabel didapat thitung 5,38> ttabel 2,01 untuk taraf signifikan $5 \%$ dengan $\mathrm{dk}=\mathrm{n}_{1}+\mathrm{n}_{2}-2=30+32-2=60$. Setelah dikonsultasikan dengan tabel didapat hal ini berarti Ho ditolak Ha diterima. Dengan demikian, hipotesis yang 
diajukan dalam penelitian ini dapat diterima kebenarannya, bahwa ada pengaruh yang signifikan model pembelajaran writing in the here and now terhadap kemampuan menulis bahan ajar mahasiswa semester VI Program Studi Pendidikani Bahasa Indonesia STKIP PGRI Lubuklinggau.

\section{Simpulan}

Berdasarkan hasil penelitian, dapat disimpulkan bahwa ada pengaruh yang signifikan model pembelajaran writing in the here and now terhadap kemampuan menulis bahan ajar mahasiswa semester VI Program Studi Pendidikan Bahasa Indonesia STKIP-PGRI Lubuklinggau. Hal ini dibuktikan dengan pengujian hipotesis diperoleh thitung $=5,37$ dan setelah dikonsultasikan dengan tabel didapat thitung $(5,37)$ $>$ ttabel $(2,00)$ untuk taraf signifikan $5 \%$ dengan $\mathrm{dk}=60$. Hal ini berarti Ho ditolak dan Ha diterima. Dengan demikian, hipotesis yang diajukan dalam penelitian ini dapat diterima kebenarannya.

Dari hasil penelitian ini membuktikan bahwa model pembelajaran writing in the here and now mampu meningkatkan kemampuan menulis bahan ajar mahasiswa. Untuk itu, bagi pengajar bahasa Indonesia dapat menggunakan model pembelajaran writing in the here and now dalam pemebelajaran bahasa Indonesia, khususnya pada mata kuliah atau materi yang memberikan keterampilan menulis.

\section{Daftar Pustaka}

Arikunto, Suharsimi. (2010). Prosedur Penelitian Suatu Pendekatan Praktik. Jakarta: Bumi Aksara.

Komaruddin, Hidayat. (2007). Active Learning. Yogyakarta: Pustaka Insan Madani.

Noermanzah, N. (2015). Peran Dosen Bahasa dan Sastra Indonesia dalam Mempertahankan Bahasa Indonesia sebagai Alat Pemersatu Negara Kesatuan Republik Indonesia pada Era Globalisasi. In Prosiding Seminar Nasional Bulan Bahasa 2015. Unit Penerbitan FKIP Universitas Bengkulu, p. 274. http://repository.unib.ac.id/11133/

Prastowo, Andi. (2011). Panduan Kreatif Membuat Bahan Ajar Inovatif. Jogyakarta: Diva Press.

Silberman, Mel. (2011). Cooperative Learning. Bandung: Alfabeta. 
Sugiyono. (2012). Statistika untuk Penelitian. Bandung: Alfabeta.

Suyatinah. (2003). Model-Model Pembelajaran. Jakarta: Rineka Cipta.

Tarigan. (2008). Membaca sebagai Suatu Keterampilan Berbahasa. Bandung: Angkasa.

Wulandari, Rina Septi. (2012). Penggunaan Model Pembelajaran Writing In The Here and Now untuk Meningkatkan Hasil Belajar tentang Materi Menulis Siswa Kelas III SDN Ampeldento 2 Kecamatan Karangploso Kabupaten Malang. Skripsi, Program Studi Pendidikan Guru Sekolah Dasar, Fakultas Keguruan dan IImu Pendidikan, Universitas Muhammadiyah Malang. http://eprints.umm.ac.id/29072/1/jiptummpp-gdl-rinaseptiw-30163-1-pendahuln.pdf.

Yaumi, M. (2013). Prinsip-Prinsip Desain Pembelajaran. Jakarta: Kencana Prenada Media Group. 